\title{
First report of grapevine Pinot gris virus infecting grapevine in Argentina
}

\author{
Humberto Debat ${ }^{1,2}$ (D) $\cdot$ Facundo Luna $^{3} \cdot$ Sabrina Moyano $^{3} \cdot$ Diego Zavallo $^{4}$ (D) $\cdot$ Sebastian Asurmendi ${ }^{4}$ (D) \\ Sebastian Gomez-Talquenca ${ }^{3}$ (D)
}

Received: 1 June 2020 / Accepted: 26 June 2020 / Published online: 8 July 2020

(C) Società Italiana di Patologia Vegetale (S.I.Pa.V.) 2020

Fourteen viruses have been associated to grapevine in Argentina (Debat et al. 2020; Luna et al. 2019). Grapevine Pinot gris virus (family Betaflexiviridae; genus Trichovirus, GPGV) was originally described in Italy and linked to grapevine leaf mottling and deformation (GLMD) in Vitis vinifera cv. Pinot gris (Giampetruzzi et al. 2012). In Latin America, GPGV has been detected in Brazil, Chile and Uruguay.

A pooled sample consisting of $V$. vinifera $\mathrm{cv}$. Torrontés and four criollas varieties from Argentina were subjected to high-throughput sequencing. Total RNAs from cambial scrapings were purified using the Spectrum Plant RNA Miniprep Kit (Sigma-Aldrich, USA) and sequenced in an Illumina Novaseq-6000 instrument generating $171,490,780$ paired reads. These

Humberto Debat

debat.humberto@inta.gob.ar

Sebastian Gomez-Talquenca gomez.talquenca@inta.gob.ar

1 Instituto de Patología Vegetal, Centro de Investigaciones Agropecuarias, Instituto Nacional de Tecnología Agropecuaria (IPAVE-CIAP-INTA), 11 de setiembre 4755, Córdoba X5020ICA, Argentina

2 Unidad de Fitopatología y Modelización Agrícola, Consejo Nacional de Investigaciones Científicas y Técnicas (UFYMA-CONICET), 11 de setiembre 4755, Córdoba X5020ICA, Argentina

3 Estación Experimental Agropecuaria Mendoza, Instituto Nacional de Tecnología Agropecuaria (EEA- Mendoza-INTA), San Martín 3853, Luján de Cuyo, Mendoza 5507, Argentina

4 Instituto de Agrobiotecnología y Biología Molecular (IABIMO), Instituto Nacional de Tecnología Agropecuaria (INTA), Consejo Nacional de investigaciones Científicas y Técnicas (CONICET), Los Reseros y Nicolas Repeto, Hurlingham, Buenos Aires 1686, Argentina reads were trimmed, filtered and mapped against a collection of plant virus sequences. $41150 \mathrm{nt}$ reads mapped to GPGV, covering $8 \%$ of its genome and suggesting the presence of GPGV in our pooled sample. Blastn of the 590 nt-long partial sequence returned $100 \%$ identity to GPVG isolate Regent-BE from Belgium (MN228488).

To confirm the presence of GPVG, the extracted RNA of each sample was random-primed, retrotranscribed using M-MLV-RT and subjected to PCR using primers GPgV5619f/GPgV6668r (Giampetruzzi et al. 2012). Only one of the tested samples (from $V$. vinifera cv. Torrontés Riojano) generated an amplification product which was cloned and bi-directionally Sanger-sequenced. The sequence obtained (MT450471, GPGV-ARG) presented a 98.6\% highest identity with GPGV isolate BC-1 from Canada (KU194413), and 98.1\% identity with the aforementioned GPGV isolate Regent-BE.

The Argentinean isolate of GPGV was found in a plant with no apparent symptoms of viral diseases. This report is of significant importance for the Argentinean viticulture as Colomerus vitis, a widely dispersed eriophyd mite and vector of GPGV is present in Argentinean vineyards. To our knowledge, this is the first report of GPGV in Argentina.

\section{References}

Debat HJ, Zavallo D, Moyano S, Luna F, Asurmendi S, GomezTalquenca S (2020) bioRxiv. https://doi.org/10.1101/2020.02.20. 957548

Giampetruzzi A, Roumi V, Roberto R, Malossini U, Yoshikawa N, La Notte P, Saldarelli P (2012) Virus Res 163:262-268. https://doi.org/ 10.1016/j.virusres.2011.10.010

Luna F, Debat HJ, Moyano S, Zavallo D, Asurmendi S, GomezTalquenca S (2019) J Plant Pathol 101:1239. https://doi.org/10. 1007/s42161-019-00298-3 